\title{
Over de grenzen van de eerste lijn
}

Citation for published version (APA):

van der Zee, J. (1989). Over de grenzen van de eerste lijn: vergelijkend onderzoek in een Europese regio. Rijksuniversiteit Limburg. https://doi.org/10.26481/spe.19890427jz

Document status and date:

Published: 27/04/1989

DOI:

10.26481/spe.19890427jz

Document Version:

Publisher's PDF, also known as Version of record

\section{Please check the document version of this publication:}

- A submitted manuscript is the version of the article upon submission and before peer-review. There can be important differences between the submitted version and the official published version of record.

People interested in the research are advised to contact the author for the final version of the publication, or visit the DOI to the publisher's website.

- The final author version and the galley proof are versions of the publication after peer review.

- The final published version features the final layout of the paper including the volume, issue and page numbers.

Link to publication

\footnotetext{
General rights rights.

- You may freely distribute the URL identifying the publication in the public portal. please follow below link for the End User Agreement:

www.umlib.nl/taverne-license

Take down policy

If you believe that this document breaches copyright please contact us at:

repository@maastrichtuniversity.nl

providing details and we will investigate your claim.
}

Copyright and moral rights for the publications made accessible in the public portal are retained by the authors and/or other copyright owners and it is a condition of accessing publications that users recognise and abide by the legal requirements associated with these

- Users may download and print one copy of any publication from the public portal for the purpose of private study or research.

- You may not further distribute the material or use it for any profit-making activity or commercial gain

If the publication is distributed under the terms of Article $25 \mathrm{fa}$ of the Dutch Copyright Act, indicated by the "Taverne" license above, 
over de grenzen van de eerste lijn

vergelijkend onderzoek in een Europese regio 



\section{over de grenzen van de eerste lijn}

vergelijkend onderzoek in èen Europese regio

Rede uitgesproken bi] de aanvaarding van het ambt van bijzonder hoogleraar in het onderzoek van de eerstelijnsgezondheidszorg aan de Rijksuniversiteit Limburg op donderdag 27 april 1989 door

dr. J. van der Zee

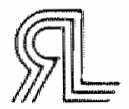

Aijksuniversiteit Limburg

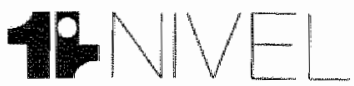

Nederlands instituut voor onderzoek van de eerstelijnsgezondheidszorg NIVEL 
CIP.GEGEUENS KONINKLIUKE BUBLIOTHEFK, DEN HAAG

Zee, d. van der

Over de gremzen van de erste lijn: vergelijkend onderzoek in een Europese re. gio / J. van der Zee. - Utrecht: Nederlands Instituut voor Onderzoek van de Eerstelinsgezondheidszorg (NIVEL)

Inaugurale rede.

ISBN 90-6905-093-5

SISO 601.5 UDC $614.2+364.444(043.5)$

Trefw: erstelijnsgezondheidszorg 
Mijnheer de rector magnificus,

Geachte toehoorders,

Toen ik aankondigde dat ik het in deze toespraak vooral wilde hebben over de unieke geschiktheid van Maastricht voor het verrichten van internationaal vergelijkend wetenschappelijk onderzoek, is mij bezworen dat een openbare les moest handelen over de leeropdracht: onderzoek van de eerstelijnsgezondheidszorg en dat ik slechts van mijn belangstelling voor internationale vergelijkingen mocht getuigen voor zover zulks functioneel zou zijn'.

Wel nu, daar houd ik mij aan; ik zal het hebben over de termen 'onderzoek' en 'eerstelijnsgezondheidszorg'. De titel van mijn bijdrage: "over de grenzen van de eerstelijn", biedt voldoende ruimte on het bloed te laten kruipen waar het niet gaan kan. Laat ik beginnen met het begrip eerstelijnsgezondheidszorg. Eerstelijnsgezondheidszorg is een bepaalde soort gezondheidszorg en well die zorg die zonder tussenkomst toegankelijk is, in een ambulante setting wordt geleverd en generalistisch van aard is of althans het meest generalistisch in zijn soort ${ }^{2}$. De hier genoemde begrippen hebben ook hun tegenpolen. Direct toegankelijk versus op verwijzing toegankelijk, ambulante versus residentieel en generalistisch versus specialistisch. Met behulp van dit begrippentrias kan men het 'eerstelijnsgehalte' van allerlei vormen van gezondheidszorg vaststellen en beschrijven. Eerstelijnsgezondheidszorg is echter meer dan een type zorg; er zit ook een duidelijkideologische/normatieve kant aan het begrip. Het is iets belangrijks; iets nastrevenswaardig. Volgens doelstelling 26 van het Health For All 2000 programma van de Wereldgezondheidsorganisatie ${ }^{3}$ dient elk land in het jaar 2000 te beschikken over een gezondheidszorg die gebaseerd is op de principes van 'primary health care'. Het normatieve element heeft vooral te maken met de rellatie tussen de drie onderdelen van het begrip. Alleen die zorg zou direct toegankelijk moeten zijn die ambulant is en generalistisch van karakter. Eerstelijnsgezondheidszorg is dan een 
middel om te komen tot een humanere gezondheidszorg en een gezondheidszorg die een efficiënter gebruik van financiële en personele middelen maakt. Het doel van onderzoek bestaat eigenlijk uit het beantwoorden van twee vragen: "is het nu well zo', "hoe zit het' en 'werkt het nu wel zo?' of 'hoe werkt het". De vraag 'is het nu wel zo?' heeft de wetenschappelijk onderzoeker gemeen met de journalist en de politieagent. Het 'hm' van Tom Poes ligt de onderzoeker in de mond bestorven. Hij is, om met Knipschild te spreken, voortdurend in de contramines. Om de vraag: 'werkt het nu wel zo?' te kunnen beantwoorden heeft de onderzoeker niet genoeg aan een kritische houding; hil moet aan zijn wetenschappelijke bagage ideeën ontlenen over de wijze waarop verschijnselen zinvol met elkaar samenhangen en moet die ideeën vervolgens toetsen aan de werkelijkheid. Ik weet niet helemaal zeker wie van de collegae Prlwytzkofsky, Sickbock, Zielknijper of Kweetal volledig aan dit profiel voldoet. Misschien alle vier wel een beetje.

Stelt men de twee genoemde elementen van 'onderzoek' ('is het nu wel zo" en 'werkt het nu wel zo') tegenover het feitelijke en het normatieve element van het begrip 'eerstelijnsgezondheidszorg', dan krijgt men vier mogelijkheden, die ik in het verdere verloop van mijn betoog zou willen uitwerken.

Eerstelijnsgezondheidszorg

Als beschrijvend begrip Als normatief ideaal

O hoe zit

$\mathrm{N}$ het

1

2

D

E

R

$Z$ hoe werkt

3

4

O het

ㄷ.

K

Voordat ikop de vier elementen afzonderlijkzal ingaan, moeter nog een opmerking vooraf worden gemaakt over de relatie tussen de twee onderzoeksvragen en het feitelijke resp. normatieve element van het begrip eerstelijnsgezondheidszorg. Het normatieve element staat op gespannen voet met onder- 
zoek. Of eerstelijnsgezondheidszorg nu goed of kwaad, mool of lelijk, nastrevenswaard of te vermijden is, is voor de onderzoeker niet zo belangrijk. De onderzoeker heeft, zellfs in een situatie waarin de door de Rijksoverheid beschikbaar gestelde middelen ter financiering van zijn instituut worden geboekt onder de begrotingspost 'versterking van de elgz' de plicht om de ontwikkelingen kritisch te blijven volgen. In mijn opvatting van mijn leeropdracht bestaan de normatieve elementen van het begrip eerstelijnsgezondheidszorg alleen als object van onderzoek en vormen de twee onderzoeksvragen 'zit het nu wel zo?' en 'werkt het nu wel zo?" evenzovele kritische kanttekeningen bij het functioneren van de verschillende delen van de gezondheidszorg. Niettemin is het goed om een onderscheid te maken tussen het beschrijvende en het normatieve element in het begrip eerstelinnsgezondheidszorg, al was het alleen maar omdat het beschrijvende element vaak ondergeschikt wordt gemaakt aan het normatieve.

\section{Eerstelijnsgezondheidszorg als beschrijvend begrip.}

We beginnen bij het eerste voorbeeld: eerstelijnsgezondheidszorg als direct toegankelijke, ambulante, generalistische zorg en we vragen ons af, of ditnuinderdaad zo is. Men kan in Nederland alle verschillendevormen van gezondheidszorg nemen en bezien of deze direct of op verwijzing toegankelijk zijn, ambulant of residentieel worden uitgeoefend dan wel generalistisch of specialistisch van karakter zijn. Ook kan men langs een andere weg onderzoeken welke vormen van zorg bijvoorbeeld in beleidsnota's of door het publiek als eerstelijnsgezondheidszorg worden beschouwd. En dan ziet men dat maar zelden alle drie de criteria van toepassing zijn op wat in het spraakgebruik als de eerstelijn wordt beschouwd. Om dat te ondervangen is bijvoorbeeld een begrip als "thuiszorg" gecreëerd, waar het feit dat de zorg 'achter de voordeur' van de zorgontvanger, of in ieder geval niet op de vestigingsplaats van de zorgverlener wordt geleverd, belangrijker is dan de vraag of de zorg rechtstreeks of op verwijzing toegankelijk is danwel generalistisch of specialistisch van aard. De specialist die een patiënt thuis bezoekt of de specialistisch verpleegkundige die de patiënt thuis verpleegt geldt wel als thuiszorg maar niet als eerstelijnszorg. Bij 'thuiszorg' is het niet-residentiële karakter van de zorg 
het belangrijkste element.

Thuiszorg is een nogal opgetuigd begrip. Neem nu de definitie van een hooggeplaatstengezaghebbend auteur: 'Onder thuiszorg verstaan we: uitgaande van de vraag naar zorg en de behoefte áán zorg een zodanige op die behoefte toegesneden bij de patiënt thuis (c.q. van huis uit te bereiken) gerealiseerde bundeling van functies, die patiënt èn gezondheidszorg èn maatschappelijke dienstverlening samen kiezen, dat de grootste kans aanwezig is, dat de hulp èn effectief zal zijn èn efficient èn satisfactie geeft aan de patiènt/cliënt"

Als men deze omschrijving ontdoet van zijn redundante elementen -het zal toch niet de bedoeling zijn dat huisbezoek van een dokter waarmee de patiënt wel tevreden is onder "thuiszorg' valt en een bezoek bij een ontevreden patiënt niet- dan staat er: "een bij de patiënt thuis gerealiseerde bundeling van functies".

In een andere publikatie van dezelfde auteur is thuiszorg 'een bundeling van funkties, erop gericht de patiënt in staat te stellen zich in zijm eigen milieu, in zijn thuissituatie, te handhaven'?. Heel letterlijk genomen zou een levensreddende spoedoperatie in het ziekenthuis ook thuiszorg zijn; ware de operatie nagelaten dan zou de patient nooit meer in zijn thuissituatie zijn teruggekeerd.

Een andere auteur (Goudriaan) ${ }^{8}$ wil juist af van het zijns inziens veel te algemene begrip thuiszorg; voor hem mag het met de vuilnisman mee. Deels omdat het te algemeen zou zijn ('thuis' is geen theoretisch interessante categorie, je hebt tenslotte ook geen bureauzorg) en deels omdat het nog te weinig algemeen zou zijn.

Want zorg is en blijft een vorm van menselijk handelen. Volgens Van Dale is het 'het streven en de pogingen die men aanwendt, de moeite die men doet om iets in stand of in goede conditie te houden of zo goed mogelijk te doen zijin of te maken" "maar ook, 'bekommernis, ongerustheid". Buiten het begrip 'zorg' vallen technische voorzieningen, die veel kunnen bijdragen aan het zo lang mogelijk in eigen omgeving handhaven. Gaat men uit van de behoefte van patiènten dan zou het menselijke zorgelementaangevuld moeten worden methulpmiddelen, technologie, woningbouw en diensten in de dagelijkse levenssfeer zoals maaltijden. Wil men het zorg-idee niet loslaten dan is de 
opvatting van Philipsen 'thuiszorg als tegenbeweging'; het afstand nemen van instellingenzorg, verhelderend ${ }^{9}$.

All met al is er niet zoveel reden om het begrip eerstelijnszorg door thuiszorg te vervangen; eerstelijnszorg is echter breder: direct toegankelijk, ambulant en generalistisch.

Maar ook bij eerstelijnszorg komt men in de problemen; beschouwt men, en daar valt veel voor te zeggen, de directe toegankelijkheid als het belangrijkste criterium dan vallen alle paramedische beroepen die de zorg ook in ambulante sfeer leveren buiten de omschrijving ${ }^{10}$. Ook de apotheker voor zover hij zijn zorg in de openbare apotheek levert op voorschriften recept van een arts behoort, als men het criterium van de directe toegankelijkheid belangrijk vindt, niet tot de eersteiijnsgezondheidszorg.

De essentiële betekenis van directe toegankelijkheid is, dat de clientèle zelf in staat geacht wordt uit te maken of men een bepaalde vorm van hulp nodig heeft. De hulpverlener van het eerste contact heeft dan wel weer de taak om de hulpvraag te verhelderen of te articuleren. Hij treedt dan op als zaakwaarnemer, als agent van de hulpvrager. In een systeem van gezondheidszorg is het vaststellen van wie er wel en niet op verwijzing toegankelijk is een belangrijke en zelfs principiële zaak. Dat in de praktijk een rechtstreeks toegankelijke zorgsoort ook vaak op verwijzing wordt geraadpleegd, is dan weer een antwoord op de vraag 'werkt het nu wel zo?'"1.

Het bovenstaande is geldig hier in Maastricht. Echter, luttele kilometers ten zuiden, ten westen en ten oosten van Maastricht in België en in de Duitse Bondsrepubliek vallen geheel andere vormen van zorg onder de door ons genoemde begrippen.

In Nederland is klinische en poliklinische specialistisch zorg alleen op verwijzing toegankelijk en duidelijk geen eerstelijnsgezondheidszorg, of het nu ambulante of residentiële zorg betreft. In Duitsland, echter, is de zorg van vrijgevestigde specialisten zonder tussenkomst van de huisarts toegankelijk en in België geldt dat niet alleen voor de ambulante maar in beginsel ook voor de residentiële zorg' ${ }^{12}$.

voor de wijkverpleegkundige, voor zover zij zich met thuisverpleging bezighoudt, geldt daar weer het omgekeerde: in Nederland kan zij rechtstreeks worden ingeschakeld; in België 
kan dit alleen op voorschrift van een (behandelend) geneesheer, terwijl in Duitsland thuisverpleging strikt deel moet uitmaken van de medische behandeling. In Frankrijk, even verder over de grens, is thuisverpleging alleen georganiseerd als 'ver-

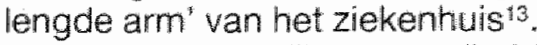

Het begrip eerstelijnsgezondheidszorg betekent in Duitsland vooral amulante versus residentiele zorg, terwijt men zich af kan vragen of voor België het begrip überhaupt wel van toepassing is; vrijwel alle zorg is rechtstreeks toegankelijk.

Hoewel de regelgeving betrekkelijk duidelijk is, kan men toch, gewapend met de vraag 'werkt het nu wei zo?', tot een nog wat genuanceerder beeld komen. Zo blijkt bijvoorbeeld uit een grootscheeps onderzoek gehouden aan het eind van de jaren zeventig in België dat mensen nietzo vaak rechtstreeks de specialist bezoeken ${ }^{14}$. Ten eerste beperkt men zich tot een aantal specialismen zoals gynaecologie, kindergeneeskunde en misschien de internist en ten tweede is het zo dat vooral jongere, beter opgeleide mensen gebruik maken van de mogelijkheid om zonder verwijzing de specialist te raadplegen. Het betreft hier een groep personen die opvallend veel gelijkenis vertoont met de Nederlandse particuliere patiënt, die weliswaar voor zijn verzekeringsmaatschappij formeel dikwijls een brief van de huisarts nodig heeft voordat een bezoek aan de speciallist vergoed wordt, maar die in de praktijk veel minder streng aan banden wordt gelegd ${ }^{15}$. Bovendien ziet men in Nederland, dat ook ziekenfondspatiënten, die voor een chronische aandoening onder min of meer permanente controle van de specialist staan, in principe ieder jaar een nieuwe verwijzing van de huisarts nodig hebben, maar in de praktijk die verwijzing zonder directe tussenkomst van de huisarts verkrijgen ${ }^{16}$.

Het is dan ook wel begrijpelijk, dat uit de sectoren van de gezondheidszorg waar mensen een min of meer permanente relatie met de zorgverschaffers hebben, zoals in de geestelijke gezondheidszorg en in de ouderenzorg. het sterkste verzet komt tegen de echelonneringsgedachte. Van Lieshout en Stoelinga (GGZ) noemen het een historische vergissing ${ }^{1 \%}$, het begrip thuiszorg is voor het eerst opgeworpen bij het beschrijven van zorg voor ouderen en hulpbehoevenden.

Door systemen van gezondheidszorg met elkaar te vergelijken kan men er achter komen hoe essentieel bepaalde vormen van 
regelgeving zilin.

Een pikant detail is overigens - om nog even op de particuliere ziektekostenverzekeraars terug te komen - de invloed van het al dan niet verzekerd zijn voor de huisarts op het gebruik van voorzieningen in de gezondheidszorg. Uit berekeningen, gebaseerd op het materiaal uit het zgn KISG-bestand (4987), blikkt dat mensen die niet voor de hulp van de huisarts zijn verzekerd, ongeveer $15 \%$ minder kosten (minder "schade') bij hum verzekeraar claimen (exclusief de kosten van huisartsenhulp). Dit blikt uit ingewikkelde modellen die verzekeraars gebruiken om hun premies en premiereducties zo scherp mogelijk te kunnen calculeren ${ }^{18}$.

Het walt te verwachten dat met het onderbrengen van de hulp van de huisarts in de voor alle Nederlanders verplichte AWBZ dit kostenremmende effect van het niet voor huisartsenhulp verzekerd zijn zal verdwijnen. Het is jammer, dat we op dit punt geen rekening houden met de ervaringen van particuliere ziektekostenverzekeraars.

Uit diezelfde berekeningenvan de verzekeraars blijktook datik, zoals ik hier voor u sta, verzekeringstechnisch tot de categorie 'brandende huizen' behoor, zoals oud-staatssecretaris Van der Reijden al eens plastisch in zijn memoires formuleerde ${ }^{19}$. Een ander voorbeeld: ook weer rond de regio Maastricht. Nu over zorg voor ouderen. Van de drie landen heeft Nederland de kleinste proportie bejaarden en hoogbejaarden. Kijkt men iets preciezer in de regio rond Maastricht, dan ziet men dat Belgisch Limburg eenzelfde type leeftijdopbouw heeft als Nederlands Limburg en dat vooral in het Luikse en de Duitse gebieden de bevolking aanzienlijk ouder is ${ }^{20}$. Niettemin is het aantal personen dat in bejaardenoorden of verpleeghuizen woont in Nederland bijna tweemaal zo hoog als in de omringende landen. Zowel in Duitsland als in België wordt de financiële positie van naaste verwanten eerst bezien voordat besloten wordt om behoeftige ouderen een bijstandsuitkering te geven. In Nederland is dat mer invoering van de Algemene Bijstandswet niet meer het geval2!. Overigens, begrijp goed, dat ik geenszins terug wil naar de situatie van voor de $\mathrm{ABW}$; ik vind het afschaffen van de onderhoudsplicht een vorm van beschaving. Maar, het heeft wel beinvloed, dat, gecombineerd met een zeer stringente regelgeving in de woningbouw, thuisverzorging en inwo- 
ning van bejaarden in Nederland een minder belangrijke rol innemen dan in de aangrenzende landen.

Zo kan men met talloze voorbeelden aantonen dat vergelijkend onderzoek de eigenaardigheden van de Nederlandse situatie kan blootleggen. De fundamenteel verschillende regelgeving op het vlak van ziekteverzuim in België, Nederland en Duitsland heeft vergaande invloed op de frequentie en vooral de duur van het verzuim in Nederland, maar dit brengt ons misschien ver van het begrip eerstellinsgezondheidszorg ${ }^{2}$.

We spraken over eerstelijnsgezondheidszorg als een feitelijke beschrijving van een bepaald type zorg en als een ideologie.

\section{Eerstelijnsgezondheidszorg als ideologie.}

Ook bij dat laatste kan men de vraag stellen 'is het nu wel zo?' en 'werkt het nu wel zo?". Een mooi voorbeeld is de discussie die enige tijd geleden is aangezwengeld over de noodzaak om een selectieve of all-omvattende (selective of comprehensive) eerstelijnsgezondheidszorg te bieden. Het is een discussie die vooral in, of, preciezer gezegid, omtrent ontwikkelingslanden speelt waarbij men de keus heeft om met een gericht interventie- of preventie-programma succes op deelterreinen te boeken dan wel een gezondheidszorg in de breedte langzaam aan op te bouwen. De effecten van het inzetten van speciale teams voor bestrijding van malaria zijn makkelijker vast te stellen dan het effect van een eerstelijnsgezondheidszorg gebaseerd op het principe van blote-voeten dokters. De discussie is fel, echter 'primary health care' is 'comprehensive' (breed) en niet selectief (smal). Selectieve eerstelijnsgezondheidszorg is technocratisch en mag misschien op deelterreinen effect hebben maar brengt zoveel problemen op langere termijn met zich mee dat aan deze oplossing niet de voorkeur moet worden gegeven aldus vele auteurs.

In een nummer van het tijdschrift 'Social Science \& Medicine', dat medio 1988 verscheen, worden de voors en tegens van de verschillende vormen van eerstelijnsgezondheidszorg naast elkaargezet23. Gelukkig zijn er ookaltijd wel mensen, die ervoor pleiten, dat het een het ander niet zozeer hoeft uit te sluiten, maar dat het toch vooral een kwestie van empirische kritiek zou moeten zijn om te zien welke benadering succesvoller is dan de andere. 
Hoewel de discussie 'selective'/"comprehensive'vooral speelt bil het bestuderen van de organisatie van de gezondheidszorg in ontwikkelingslanden, bevat ze elementen die voor een land als Nederland buitengewoon van belang zijn.

ledere generalistische vorm van zorg moet het afleggen tegen specialistische vormen als men kijkt naar effectiviteit op een bepaald deelterrein. Legio zijn de rapporten waarin aangetoond wordt dat de huisarts niets weet van. . . vul maar in en op deze punten vooral grondig zou moeten worden bijgeschoold. Enkele recente krantekoppen, NRC Handelsblad van 24 september 1988: KENNIS VAN REANIMATIE BIJ HUISARTSEN VOLGENS TEST ZEER TELEURSTELLEND. Haagsche Courant van 5 oktober 1988. Uit NIVEL-onderzoek blijkt: HUISARTSEN DOEN TE WEINIG AAN HET VOORKOMEN VAN ZIEKTEN. Deventer Dagblad van 30 september 1988: SEKSUOLOGISCHE HULPVERLENING VAN DE HUISARTS LAAT NOGAL TE WENSEN OVER. Tenslotte Trouw 13 april 1988: LEER ARTSEN MEER OVER HET BESTRALEN VAN PATIENTEN. De teneur van de perspublikaties is duidelijk: huisartsen weten er weer niets van en falen op essentiële punten.

Maar, "is dit nu wel zo"?

Enkele jaren geleden speelde zich in het Tijdschrift voor Sociale Geneeskunde een interessante discussie af tussen de hoogleraren Schudel (GGD Den Haag) en Diekstra (Rijksuniversiteit Leiden). ${ }^{24}$ Diekstra had met enkele collegae, gebruik makend van de gegevens uit het $\mathrm{NHI}$-peilstationsproject uitgezocht, dat van de door de peilstations-huisartsen gerapporteerde gevallen van pogingen tot zelfmoord bij hun patiënten, ongeveer de helft in de weken daarvoor een bezoek aan hun huisarts had gebracht; achteraf bezien dikwijls met klachten van psychosociale aard. Naar aanleiding van de publikatie van de onderzoeksresultaten in het Tijdschrift voor Sociale Geneeskunde verschenen krantekoppen, vergelijkbaar met de hierboven genoemde of nog scherpere. 'Arts Zou Zelfmoord Niet Aankunnen' en 'Suïcide - Het Falen Van De Hulpverlening'. Schudel reageert op het artikel maar vooral op de perspublikaties met de "naald in de hooiberg'-theorie. Hij berekent dat de huisarts eens per anderhalf jaar iemand op zijn spreekuur krijgt, die nadien zelfmoord pleegt. Schudel stelt dat huisartsen uiter- 
aard zeldzaam optredende ziektegevallen moet kunnen herkennen, maar dat in het geval van de contacten woorafgaande aan de sulicidepoging, in het algemeen geen sprake is van sterk in de richting van sulicide wijzende klachten. Als de huisarts op alle bijvoorbeeld depressieve patiënten zou reageren alsof het om een dreigende zelfmoord zou kunnen gaan, dan zou hij grotelijks overreageren.

Dieksta e.a. reageren met de mededeling dat zij niet verantwoordelijk zijn voor de krantekoppen en dat Schudel's berekeningen niet kloppen; sulicidepogingen komen vaak genoeg voor om in de huisartspraktijk van klinisch belang te zijn. Schudel's naald is volgens hen een speldenkussen.

Ik haal met opzet deze discussie wit het begin van de jaren tachtig aan omdat het zo'n scherp voorbeeld is van het dilemma van de generalistisch zorg. Word je als huisarts geacht om naalden in hoolbergen te vinden en zo nee, hoe groot moet de naald zijn en hoe klein de berg? Mag de generalist zich verschuilen achter 'hoeven we niet te weten, hebben we niet gehad'?

Uiteindelijk mag hij dat niet, getuige een geruchtmakende uitspraak van het Medisch Tuchtcollege te Eindhoven, die een huisarts berispte omdat deze oordeelde dat een vrouw geen tumor in haar borsthad na palpatie eneen (herhaalde) mammografie. Volgens de tuchtrecher had de arts de patiënt naar de chirurg moeten verwijzen. Deze uitspraak heeft fel commentaar opgeroepen uit de beroepsgroep van huisartsen; dat heeft niet mogen baten ${ }^{25}$. Huisartsen moeten, heel formeel gesproken, op 'safe' spelen.

Dit speelt niet alleen in de huisartsenzorg; ook in de verpleegkunde wordt deze discussie gevoerd. Speciale verpleging, zoals extramurale verpleging voor kinderen met astma is vast en zeker op sommige punten veel deskundiger dan de algemeen opgeleide wijkverpleegkundige. Men zou er echter niet aan moeten denken dat elke ziekenhuisafdeling gespecialiseerde verpleegkundige zorg buiten de muren zou brengen. Organisatorisch zou dat een chaos geven. Bovendien zou een aantal belangrijke aspecten van het werk van de verpleegkundige dan onderbelicht blijven. Het generalistisch karakter van de eerstelijnsgezondheidszorg is niet alleen belangrijk omdat het als een soort makelaarskantoor optreedt in een vergaand gespecialiseerde wereld maar ook omdat, en dat geldt vooral in 
de zorgsector, het generalisme staat voor een (humane) bejegening van degene die zorg behoeft als tegenhanger van het technische, projectmatige. De terminologie ontleen ik, zoals $u$ begrepen zult hebben, aan Philipsen.

Het is goed dat er onderzoek is om vast te stellen in welke mate eerstelijnsgezondheidszorg generaal dan wel specialistisch van karakter kan zijn. Het is namelijk ook duidelijk dat het permanent bestoken van generalisten met specifieke nascholingsprogramma's geen enkel zinvol effect heeft. Men kruipt in zijn schulp en wordt de lust benomen om zich op enig vlak verder bij te scholen. Tekenend voor de gevoelens onder huisartsen is het Ten Geleide van de redactie van het Jaarboek Huisartsgeneeskunde 1988. De redactie verontschuldigt zich over het uitbrengen van nog een Jaarboek met de volgende woorden; 'Wordt de huisarts nog niet genoeg geteisterd door de aanhoudende stroom van belerend drukwerk die vanaf de hoogvlakten der Hooggeleerdheid wordt uitgestort over zijn vege generalistenlijf?'26. Het zij toegegeven, fraai proza is het niet, maar wel zeer duidelijk.

Het curieuze van nascholing is, dat als artsen de keuze hebben, ze vaak datgene kiezen waar ze al een zekere deskundigheid in bezitten'2?

Ik zou zelf niet goed weten welke kant het op moet met de nascholing. Moet het in de richting van steeds meer protocollen en standaarden; de huisarts als homo algorithmicus of moet men hem juist trainen om zijn intuitie, zijn gevoel van 'pluis' of 'niet pluis' aan te scherpen, of moet de huisarts geleerd worden met behulp van geavanceerde informatietechnologie alles op te kunnen zoeken? Het lijken me zinvolle vragen voor onderzoek. Het is geen eenvoudig onderzoek, omdat men zachtere elementen van de eerstelijnsgezondheidszorg zal moeten meten en kwantificeren maar in beginsel is dat heel goed mogelijk. Het is ook hier dat onderzoek de meest zinvolle bijdrage kan leveren, omdat het niet terecht zou zijn om alles wat onder dit kopje als ideologie wordt betiteld als irrelevant ter zijde te schuiven.

Op het moment dat er van meerdere kanten specialistische zorg wordt geleverd, hoort men onmiddellijk de roep om een case-manager, een generalist, die de verschillende specialistische vormen coördineert en op elkaar afstemt. Het is alleen 
rijkelijk laat wanmeer men daar pas achter komt als de bestaande eerstelijns-vormen van generalistische zorg bezweken zijn onder het specialistische geweld.

Een aardig voorbeeld is de thuisverpleging in Frankrijk. Traditioneel wordt thuisverpleging in Frankrijkgeorganiseerd als nazorg na de opname in een ziekenhuis. Elk ziekenhuis stuurt verpleegkundigen uit of maakt gebruik van extramurale verpleegkundigen om opgenomen patiënten verder te verzorgen. In Frankrijk beginnen echter stemmen op te gaan om wellicht een algemeen verpleegkundige in het leven te roepen die ook kan voorkómen dat mensen in het ziekenhuis worden opgenomen. Met veel esprit wordt hier de wijkverpleegkundige uitgevonden.

Uit de gepresenteerde voorbeelden zal het de toehoorder duidelijk zijn dat ik me juist in Maastricht op mijn gemak voel. Je hoeft maar een paar stappen te doen en je zit in het buitenland; de regio leent zich uitstekend voor internationaal vergelijkend onderzoek. De werktitel van deze oratie is ook lang geweest; 'Met de rug naar Den-Haag'. Waarbij ik doel op de neiging van Maastrichtenaren en vooral van de universitaire bevolking om zich te oriënteren op wat er in Den-Haag en Zoetermeer gebeurt in plaats van zich te richten op de unieke situatie waarin men zelf verkeert. Juist op het gebied van gezondheidszorg treft men in beperkt geografisch gebied grote verschillen in organisatie, financiering en andere regelgeving, terwijl de sociaal-culturele scheidslijnen tussen de inwoners van het gebied veel vioeiender zijn. Ik heb dit al met voorbeelden geillustreerd. De aanwezigheid van universiteiten in Aken, Hasselt, Düsseldorf, Keulen en ook Nancy maakt dat netwerken van onderzoeksinstituten, vakgroepen en onderzoekers weinig fysieke belemmeringen hebben om tot stand te komen. Om echter van praten oververgelijkend onderzoek tot het verrichten van onderzoek te geraken, zou ik er voor willen pleiten om een speciaal fonds, gevoed door al die universiteiten en nationale, regionale en lokale overheden in het leven te roepen en wel op korte termijn. Dan kan men pas goed aan de slag.

Er is een belangrijke voorafgaande onderzoeksvraag: Is de regio nu inderdaad wel zo cultureel homogeen als ik veronderstel? Men zou het onderzoek van Geert Hofstede moeten herhalen om te zien of de Limburger, de Rijnlander, de Waal, de 
Elzasser, de Bourgondiër meer op elkaar lijken met betrekking tot de door Hofstede geformuleerde waardedimensies als onzekerheidstolerantie, autoriteitsgevoeligheid, feminiteit dan op de grootste gemene deler van hun landgenoten ${ }^{28}$. Gegevens over dit type opvattingen worden in zijn algemeenheid als nationale cijfers gepresenteerd en niet uitgesplitst naar deelgebieden. Als men ook waarden en opvattingen op het gebied van de gezondheid en de gezondheidszorg in dit vergelijkend onderzoek zou opnemen, zoals Philipsen in zijn laatste boek aanbeveelt ${ }^{29}$, dan zou men een goede basis hebben om te onderzoeken wat wet en regelgeving, financiering en het aanbod van voorzieningen nog aan extra verklaring hebben te bieden voor de mate waarin en de wijze waarop men van deze voorzieningen gebruik maakt. Hiervoor is het nodig dat er goede samenwerkingsverbanden komen tussen de universiteiten in de regio rond Maastricht, niet alleen met de Akense TH maar ook met de algemene universiteiten die iets verder weg liggen.

Men moet dan niet vergeten dat de Leidse socioloog Van Heek, die de invloed van sociaal-culturele verschillen op het geboorteniveau van Nederlandse en Belgische katholieken aan weerszijde van de Belgisch-Nederlandse grens, onderzocht, juist tot de conclusie kwam dat de grens wel degelijk een sociaal-culturele barrière van de eerste orde was ${ }^{30}$.

Aan het eind van deze oratie gekomen, wil ik gaarne enkele woorden van dank spreken aan degenen die mij op deze universiteit hebben geintroduceerd en begeleid.

Allereerst de leden van de commissie van toezich op deze bijzondere leerstoel, Jozien Bensing, Ferd Sturmans, Hans Philipsen en Clemens Olthoff. Ik hoop datjullie aan je toeziende taak bijzonder weinig werk zullen blijken te hebben.

Het Bestuur van de Stichting NIVEL en het College van Bestulur van de $R L$ dank ik voor het initiatief tot het instellen van de leerstoel. Op deze wijze wordt vorm gegeven aan een samenwerking met een buitenuniversitair onderzoeksinstituut werkzaam op een gebied waar ook deze universiteit bijzondere aandacht schenkt: de eerstelijnsgezondheidszorg.

Hooggeleerde Philipsen, Best Hans, Als mijgevraagd wordt, waar ik sociologie heb gestudeerd, dan 
zeg ik: dat was in Leiden bij Hans Philipsen. Hij is mijnleermeester geweest. Vraagt men mij: Wat heb je dan van hem geleerd, dan ben ik wat minder beslist in mijn antwoord. Het is eerder een gevoel van respect en bewondering, als je weer eens aan iets waar ik honderd keer voorbij gelopen ben zonder er aandacht aan te schenken, de meest interessante en belangwekkende eigenschappen ontdekt. Die gave heb ik helaas niet van je kunnen leren. Je bent niet iemand die school gemaakt heeft; je hebt wel bewonderaars.

Hooggeleerde Drop, Zeer geleerde Diederiks en Stevens, Beste Riet, Jos en Fred,

Als collega"s in de vakgroep Medische Sociologie hebbenjullie ereen wat vreemde eend bijgekregen. Socioloog qua opieiding maar, zoals ik altijd zeg, ik heb later veel bijgeleerd en ben eigenlijk nauwelijks gewend binnen een vakgroep van sociologen me disciplinair te gedragen. Ik werk met plezier in de vakgroep Medische Sociologie, ook omdatik veel mensen nog van lang geleden ken. Er is me één ding opgevallen: door de sterke vervlechting van de vakgroep met de werkzaamheden van de medische faculteit wordt de medisch sociologie voor een belangrijk deel gebruikt om te helpen bij het opsporen van redenen waarom mensen ziek worden en het vinden van middelen om ze te genezen of hun lijden te verlichten. Medische sociologie aan de RL is sterk patiënt- of bevolkings-gericht. Een hele medisch-sociologische school die zijn aandacht richt op de hulpverleners, de beslissersen de doorhen uitgeoefende macht en invloed valt eigenlijk buiten het bestek van het werk van de vakgroep. Gegeven de integratie binnen de medische faculteit is dat begrijpelijk, maar zelf kom ik nu juist van een instituut dat zich sterk op de hulpverlener en de hulpverlening heeft gericht en probeert uit te zoeken hoe diens beslissingen

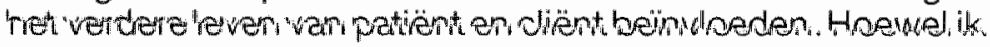
slechts in deeltijd bij de vakgroep aanwezig ben en maar zelden in Uw midden verkeer, hoop ik toch dat mijn inbreng vanuit de hulpverlenerskant een aanvulling op Uw werkzaamheden kan vormen.

Dames en Heren collega's, medewerkers van het NIVEL. U maakt deel uit van een betrekkelijk overzichtelijke organisatie en dat heeft enkele plezierige aspecten als je samen dingen moet doen. Ik dank $U$ voor Uw tolerante houding tegenover 
mijn afwezigheid en en voor Uw bijdrage aan het plezierige en produktieve werkklimaat van ons instituut.

Dames, heren en studenten, ledere oratie eindigt met de opmerking dat het zo plezierig isom samen met $U$ de gezondheidszorg op wetenschappelijk wijze teverkennen. U moeter wel zijn want ik zie regelmatig in de kantine als ik daar een lunch geniet, jongelui die qua leeftijd en voorkomen niet anders dan studenten kunnen zijn, maar om nu te zeggen dat we veel contact hebben, nee. Uw op zich goed doordachte en gewaardeerde, maar docent-onafhankelijk systeem van onderwijs houdt echter voor iemand aan de periferie in, dat er in het onderwijs nauwlijks plaats is. Misschien dat ik $u$ als AlO bij het verdere, liefst internationaal vergelijkende onderzoek weer tegen kom.

Ik heb gezegd. 

noten 
1.

Mel dark aan Fons Gloerich voor zijn hulp bill de onderbouwing van dit verhaal en aan Jozien Bensing voor haar waardevolle commentaar.

2

Volgens de 'Schets' van de eerstelinsgezondheldszorg (Ministerie van Volksgezondheid \& Milieuhyglëne, 1980) heeft dit begrip de wolgende kenmerken:

- generalistisch karakter

- vrije toegankelijkheid

- situering dichtbij of temidden van de doelpopulatie

- gericht op de mens in zijn thuissituatie

- ambulante wijze van hulpverlening

Als men 'residentieel' als pendant van "ambulant' beschouwt, dan kan men "gericht op de mens in diens thuissituatie" als een voorwaarde daarvoor beschouwen.

Het belangrijkste is dat de patient niet wordt 'opgenomen' in de omgeving waar de hulp wordt geboden.

Het kenmerk 'temidden van of dicht bij de doelpopulatie' is wat moeilijker te plaatsen. Het is op het eerste gezicht wel duidelijk wat ermee wordt bedoeld. Zorg, die echter alle kenmerken heeft behalve de laatstgenoemde is niet goed voorstelbaar (huisartsen uit Engeland?), omdat een doelpopulatie altijd impliciet deel uitmaakt van de omschrijuing.

3.

Over verschillen en overeenkomsten tussen het WHO-primary health care begrip en het bij ons gebruikelijke begrip "eerstelijnsgezondheidszorg' is al het nodige gezegd en geschreven.

Het oorspronkellike primary health care begrip is veel breder dan ons begrip eerstelinsgezondheidszorg of eerstelijnszorg. Het omvat ook de publieke gezondheidszorg. Het is (Alma Ata declaration) "The first level of contact (...)with the national health system" "maar een zin als "(..) involves, in addition to the health sector, all related sectors and aspects of national and community development, in particular agriculture, animal husbandry, food industry, education, housing, public work, communication and other (sic!) sectors, and demands the co- 
ordinated effort of all these sectors", geeft genoegzaam aan wat ik bedoel. (WHO, Alma Ata Declaration, 1978).

4.

Dit is een wat onorthodoxe omschrijving van onderzoek. Meestal (zie bijv. Kerlinger, Foundations of behavioral research: London, Holt, Rinehart\&Winston, 1977) benadrukt men het theoretische, systematische karakter van onderzoek: "Scientific research is systematic, controlled, empirical and critical investigation of hypothetical propositions about the presumed relations among natural phenomena". (Kenlinger, $0 . C_{\text {.; }}$ 1977, p11)

Ook wordt vaak (Swanborn, P.G., Methoden van sociaal-wetenschappelijk onderzoek, Assen, Boom, 1981, Vercruysse, E.V.W., Het ontwerpen van een sociologisch onderzoek. Assen, Van Gorcum \& Comp, 1966) een onderscheid gemaakt tussen beschrijvend (hoe zit het) en verklarend onderzoek gemaakt (waarom werkt het 20$)$.

Good Old Nagel (E. Nagel, The structure of science, London, Routledge \& Kegan Paul, 1968) relativeert het verschil tussen het "hoe' en het 'waarom', in die zin dat hij stelt dat de meeste wetenschappen de vraag naar het 'waarom' niet (kunnen) beantwoorden. Na eerst gesteld te hebben "Explanations are answers to the question "Why?" zwakt hij deze stelling ernstig af.

(...) "No science (and certainly no physical science), so the objection runs, really answers questions as to why any event occurs, or why things are related in certain ways.

Such questions could be answered only if we were able to show that the events which occur, must occur and that the relations which hold between things must hold between them. However, the experimental method of science can detect no absolute or logical necessity in the phenomena which are the ultimate subject matter of every empirical enquiry; and, even if the laws and theories of science are true, they are no more than logically contingent truths about the relations of concomittance or the sequential order of phenomena. Accordingly, the questions which the sciences answer are questions as to how (in what manner or under what circumstances) events happen and things are related. 
The sciences theretore achieve what are the at best only comprehensive and accurate systems of description, not of explamation."

5.

Het verschil tussen het neutrale 'hoe zit het' en het sceptische 'is dit nu wel $20^{*}$ zit hem in de verhouding tot de constante stroom niel of nauwelliks gefundeerde uitspraken over de gezondheldszorg en het gezondheidszorgbeleid; de "waan van alledag". Op dat punt is de onderzoeker inderdaad in de contramine. Zie P. Knipschild. Epidemiologie in de contramine, oratie Maastricht, 1985.

6.

VanLonden, J. "Thuiszorg, huiswerk voor allen, vóór het jaar 2000" Utrecht, Rijksuniwersiteit, vakgroep Algemene Gezondheidszorg en Epidemiologie, 1987.

7.

Van Londen, d., lezing op het congres 'Thuiszorg en Techniek'. Gepubliceerd in Smeets, J.W. (red.), Thuiszorg en Techniek, Delft, Universitaire Pers, 1988.

8.

Goudriaan, G., Thuilszorg tussen de lijnen, "s Gravenhage Harmonisatieraad Welzijnsbeleid, 1988.

Zle ook, Goudriaan, G., Tijdschrift voor Gezondheid en Politiek, december 1988 .

9.

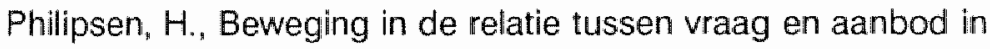
de thuiszorg; bijlage III in H. Philipsen "Gezondheidszorg als project en bejegening, Maastricht, Rijksuniversiteit Limburg, 4988.

10.

Directe versus op verwijzing toegankelijkheid is in de typologie van de Canadese econoom Robert Evans (R.G. Evans, Incomplete vertical integration: the distinctive structure of the health care industry, in J. Van der Gaag en M. Perlman (eds): Health, econo- 
mics and Health economics, Amsterdam, North Holland Publishing Company, 1981) het enige kenmerk waarop "primary care providers' zich van 'secondary care providers' onderscheiden.

De mate van vervlechting en wederzijdse afhankelijkheid van primaire en secundaire hulpverleners is een belangrijk analytisch instrument voor het beschrijven van de organisatie van de gezondheidszorg. Organisatorische eenheden van primaire en secundaire voorzieningen hebben een buitengewoon krachtige marktpositie; veelal wordt het ontstaan van dergelijke eentheden door regelgeving onmogelijk gemaakt (zie te onzent het verbod op maatschapsverbanden die zowel huisartsen als specialisten of zelfs specialisten van verschillende disciplines omvatteny.

In de beheersing van de gezondheidszorg is een begrip als verticale integratie van groot belang. Zijn er rechtstreekse beheersrelaties tussen financiers, leveranciers en afnemers van zorg? Soms beheersen de leveranciers de financiering (de zogenaamole dokters- of Maatschappij- (i.e. Maatschappij tot bevordering der Geneeskunst) fondsen in Nederland. Gebruikelijker (maar niet (meer) in Nederland) is het dat de financiers de leveranciers rechtstreeks beheren. In België kunnen ziekenhuizen eigendom van ziekenfondsen zijn. In 1982 was dat voor $9 \%$ van de zieken. huisbedden het gieval (zie Glloerich, A.B.M., R.T.J. Hamers, J. van der Zee \& P.P. Groenewegen, Regional variation in hospital admission rates in the Netherlands, Belgium and the North of France: basic information and references, Utrecht, Nivel, 1989)

Zijn de verzekeraars op hun beurt weer consumentencoöperaties (zoals het ziekenfonds Azivo in 's Gravenhage) dan is de kring weer gesloten. Verschillen in regelgeving tussen landen betreffende het tegengaan of mogelijk maken van verticale integratie vormen een uiterst relevant studie-object.

\section{1.}

Volgens Kerkstra (Commumity nursing in the Netherlands, lezing gehouden op de internationale conferentie over community nursing, 16/17 maart 1989, 's Hertogenbosch) wordt het Kruiswerk slechts in $27 \%$ van de gevallen rechtstreeks geraadpleegd. In andere gevallen op verwijzing. 


\section{2.}

Zie voor De Duitse Bondsrepubliek: S. Eichhorn, 'Germany', in M. Raffel (ed) Comparative Health Systems, Pennsylvania State University Press, 1984.

Door verschillende auteurs wordt gewezen op de forse kloof tussen ambulante en residentiële zorg in de Duitse Bondsrepubliek (zie bijv. B.Kosanke, Cooperation between different professions and lay personnel in: $U$. Laaser, R. Senault \& H. Viefhues, Primary health care in the making, Berlin-Heidelberg, Springer Verlag, 1985)

Voor België zle: Groenewegen, P.P. en X. Leroy, De aanbodzijde in de Nederlandse en Belgische gezond heidszorg in R.F. Peeters, F.C.J. Stevens \& J. van der Zee, Basisgegevens van de Belgische en Nederlandse systemen van gezondheidszorg en sociale zekerheid bif ziekte en invaliditeit, Deventer, Van Loghum Slaterus, 1985.

\section{3.}

De strikte koppeling tussen medische behandeling en verpleegkundige verzorging in de Duitse thuisverpleging wordt beschreven door Eichhorn (o.c.) en door Belstler (Martha Belstler, Thuisverpleging in Duitsland, organisatie en financiering in: Thuisverpleging in de eerstelijnsgezondheidszorg, Wit Gele Kruis van België, Leuven, Acco, 1983.

Kenmerkend voor de Belgische thuisverpleging is de sterk verrichtingen-georiënteerde financiering. (zie $\mathrm{H}$. van Loon, Which acts do nurses perform in home-care services, paper presented at the international conference on community nursing, 's Hertogenbosch, 16/17 maart 1989)

In Frankrijk wordt de thuisverpleging vooral als verlengstuk van de ziekenhuisverpleging gezien en georganiseerd. D. Artot, Community nursing in France, paper presented at the international conference on community mursing,'s Hertogenbosch, 16/17 maart 1989. Zle ook T.J.J.M.T. Kersten, Home care after hospitalization in: J. Bosman, H. Kroon \& J. van der Zee (red) Hospitals and primary health care in the Netherlands, Utrecht, Nivel/NZI, 1989. 
14.

Nuyens, Y. De eerste lijn is krom, Deventer, Van Loghum Slaterus, 1980 . Zle hoofdstuk 3 van deze samenvatting van het project eerstelijnsgezonheidszorg uit het Nationaal Programma in de sociale wetenschappen. (tabel 26, p165 voor de frequenties van contact (rechtstreeks of op verwijzing), en tabel 28 voor de determinanten van contact met huisarts of specialist)

15.

Het is overigens merkwaardig dat ik voor dit eenvoudige ervaringsfeit geen nadere adstructie in de litteratuur heb kunnen vinden (ook niet het tegendeel; er is gewoon heel weinig geschreven over particuliere ziektekostenverzekeringen in het algemeen en dit aspect in het bijzonder). Er is - op de Verenigde Staten na geen land ter wereld waar zulk een groot deel van de verzekeringen tegen ziektekosten niet in publieke handen is. Toch bestaan er geen overzichten waarin de werkwijze van particuliere ziektekostenverzekeraars beschreven staat. Wel is bekend wat de effecten zijn van verschillende in omloop zijnde verzekeringsvarianten; daarop kom ilk nog terug (noot 18).

16.

In het midden van de jaren zeventig, is er, naar aanleiding van het proefschrift van De Melker, een discussie (in Medisch Contact) geweest over thet routinematig verstrekken van verwijskaarten door de huisarts. (Pel J.Z.S., Over de invioed van de huisarts op het werwijspercentage, Medisch Contact, 30 "1975, 988-989; zie ook De Melker, R.A., Over de invloed van de huisarts op het verwijspercentage, Medisch Contact, 30, 1975, 1145-1146).

De Melker's stelling was, dat de huisarts zich veel aktiever zou kunnen opstelling tegenover deze zogenaamde verlengingsverwijskaarten. Eens verwezen, bliff verwezen hoeft niet de praktijk te zijn. Op dit punt is er echter niet veel veranderd. Studies uit het midden van de jaren tachtig laten nog steeds zien dat slechts ongeveer de helft van de werwijzingen van huisartsen als aktieve beslissingen te kenschetsen zijn. (43\% aktieve huisartsen in: Gloerich A.B.M., V. Schreynemaekers en J. van der Zee, Referral rates in sentinel practices, in A. Bartelds, J. Fracheboud, \& J. van der zee (red), The Dutch sentinel practice network; relevance for 
public health policy, Utrecht, Nivel, 1989. Sixma, H.J.M., Contacten en verwijzingen bij de Almeerse huisartsen ( $46 \%$ aktieve verwijzingen) Utrecht, Nivel, 1986. Nijhout, F.P. en J.P. Dopheide ( $54 \%$ aktieve verwijzingen) Een ziekenhuis op Nieuw Land, Utrecht, $\mathrm{NHI}, 1983$.

\section{7.}

Lleshout, Peter van en Ben Stoelinga, Echelonnering in de geestelifke gezondheidszorg: een historische vergissing, Maandblad Geestelijke Volksgezondheid, 43, 1988, 243-252.

18.

Deze wijsheid heb ik niet van mijzelf, maar van mijn oud-collega Bouke Posthuma, hoofd research van AEGON Schadeverzekering NV. In een deels multiplicatief, deels additief schattingsmodel, dat als variabelen bevat: dekkingsvorm (klasse 2,3), hoogte elgen risico (in 3 klassen), collectief of individueel verzekerd zijn, het al dan niet voor huisartsenhulp verzekerd zijn en een aantal leeftijds- en sexecategorieën, vindt hij dat het niet verzekerd zijn voor de hulp van de huisarts tot gemiddeld $15 \%$ lagere claims leidt. Een eigen risico van meer dan 750 gulden levert (daarbovenop) nog eens gemiddeld $30 \%$ lagere kosten op. Bij de berekeningen zijn de claims voor huisartsenhulp niet meegerekend. Bij de hoogte van het eigen risico zal wel meespelen hoe men zijn gezondheid taxeert (ook is er weer zeer weinig bekend over het 'verzekeringsgedrag' van degenen die een hoog eigen risico nemen; past men dit aan in de loop van de tijd; hoe reageert een verzekerde als zijn eigen risico 'vol' is; wat wordt er überhaupt niet geclaimd), maar bij het al dan niet voor huisartsenhulp verzekerd zijn ligt zulks minder voor de hand. Het ziet er naar uit dat het hier om een reëel verzekeringseffect gaat.

19.

Van der Reijden, J.P., Onze kostelijke gezondheidszorg, Amsterdam, Uitgeverij Balans, 1987, p.175.

20.

Voor de regio rond Maastricht gelden de volgende percentages 'bejaarden' (1985): 
provincie Luik (Belgie)

provincie Limburg (Belgie)

provincie Limburg (Nederlarnd)

Regierungsbezirk Dusseldorf (BRD)

Regierungsbezirk Köln (BRD)
* inwoners inwoners

$\geq 65$ jaar $\geq 75$ jaar

In Nederland was per 1-1-1985 7,7\% van de bevolking in bejaardenoorden of verpleeghuizen woonachtig (dit percentage was op 1-1-1988 teruggelopen tot $7,1 \%$ ). Voor de Duitse deelstaat Nordrhein Westfalen was dit getal per 1-1-1984 4,53\% (Wolff, Altheimplätze und Alterspflegeplätze in Nordrhein Westfalen, Zeitschrift für Gerontologie, 21,1988,52-54).

Voor België dateren de laatste cijfers uit de volkstelling van 1981; Dooghe en Van den Boer noemen een getal van $5,1 \%$ (G. Dooghe en L. Van den Boer, Care for the elderly in Belgium, CBGS, Werkdocument nr.37, Brussel, 1987).

21.

Knipscheer, C.P.M., De familiezorg binnen het bejaardenbeleid: stand van zaken en ontwikkelingen. Gezondheid \& Samenleving, $5,1984,80-92$.

22.

Prins, R en R.F. Peeters, Afwezigheid wegens ziekte in België en Nederland, Gezondheid en Samenleving, 6, 1985, 296-303.

23.

Rifkin, Susan \& Gill, Walt, Selective or comprehensive primary health care?, Social Science \& Medicine, 26, 9, 1988, p877-977. Zle vooral de bijdrage van Duane L. Smith \& John H. Bryant, Building the infrastructure for primary health care; an overview of vertical and integrated approaches (p 909-917).

24.

Diekstra, R.W.F, A.C. de Graaf \& M. van Egmond, Over de epide- 
miologie van suïcidepogingen, Tijdschrift voor Sociale Geneeskunde, 60, 1982, 398-404. Schudel, W.J. Epidemiologie van suïcidepogingen: een naald in de hooiberg. Tijdschrift voor Sociale Geneeskunde, 60, 1982, 549-550. Diekstra, R.W.F., A.C. de Graaf en M. van Egmond, Schudel's hooiberg is een speldekussen, Tijdschrift voor Sociale Geneeskunde, 60, 1982, 550.

25.

Uitspraak Medisch Tuchtcollege te Eindhoven, Medisch Contact, $37,1982,250$.

26.

Jaarboek voor de huisarts, 1988, Utrecht, Wetenschappelijke Uitgeverij Bunge.

27.

Sibley, J.C., D.L. Sackett, V. Neufield, B. Gerrard e.a., A randomised trial of continuing medical education, The New England Journal of Medicine, 306, 1982, 511-515.

28.

Hofstede, Geert, Culture's consequences, international differences in work-related values, Beverly Hills/London/New Delhi, Sage Publications, 1987 (3rd printing).

29.

$\mathrm{H}$. Philipsen, Gezondheidszorg als project en bejegening, Waarden ten aanzien van ziekte, gezondheid en samenleving, Maastricht, Rijksuniversiteit Limburg, 1988.

30 .

F. van Heek, Het geboorte-niveau der Nederlandse Rooms-katholieken, Leiden, H.E. Stenfert Kroese NV "1954. 